\title{
VEGETABLE-BASED FEED FORMULATION ON POULTRY MEAT QUALITY
}

\section{Omenka $\mathrm{RO}^{1}$ and Anyasor GN*1}

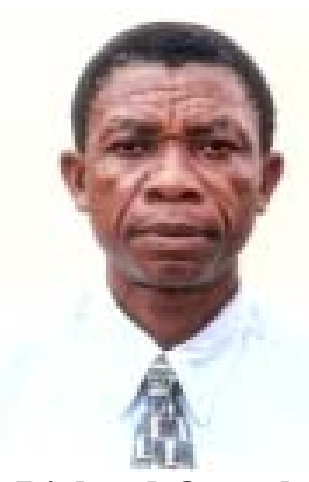

Richard Omenka

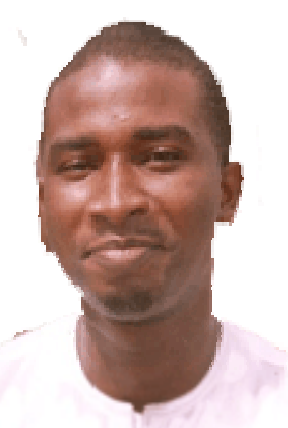

Godswill Anyasor

*Corresponding author e-mail: gencc144@yahoo.com

${ }^{1}$ Department of Chemical and Environmental Sciences, School of Science and Technology, Babcock University. P.M.B. 21244, Ikeja, Lagos 100 000, Nigeria. 


\section{ABSTRACT}

Modern poultry production is based on manipulation of genetics and environmental factors that affect intensively farmed poultry. This includes feeding well balanced and hygienically produced feeds to highly productive lines of birds. Feed formulation involves combining different ingredients in proportions necessary to provide the animal with proper amount of nutrients needed at a particular production stage. Green leafy vegetables are rich sources of essential amino acids, vitamins, minerals and antioxidants and the cheapest in terms of affordability and most abundant source of proteins. Therefore, this study was aimed at investigating the effect of vegetablebased feed on the nutritive quality of broiler meat. Fifty-day old broiler chicks were randomly distributed into two groups (25 chicks per group). One group was administered with experimental (vegetable-based) diet and the other group with standard (commercial broiler starters) diet. The experimental diet was formulated to contain the same composition with control diet substituting pumpkin leaves, pawpaw and banana in place of lysine, methionine and vitamin pre-mix. The trial-and-error method of feed formulation was adopted during preparation of experimental feed. Results from proximate analysis revealed a significant $(\mathrm{P}<0.05)$ higher crude protein $(15.75 \pm 0.14 \%)$ and moisture content $(23.3 \pm 2.36 \%)$ in vegetable-based formulated feed than the crude protein $(9.63 \pm 0.13 \%)$ and moisture content $(16.7 \pm 2.23 \%)$ of the control feed. The ash $(10.0 \pm 4.08 \%)$ and fat $(2.5 \pm 0.78 \%)$ composition of both the standard and vegetable-based feeds were found to be similar. At the end of 6-week treatment, there was no significant difference in the mean weight of birds' organs (head, gizzard, heart, lung, small intestine, large intestine, upper limbs) examined. However, the weight of limb and lung of the experimental group were lower compared to the control group. The total serum cholesterol and mean fat content of heart, gizzard and muscles of the vegetable fed birds were found to be significantly lower $(\mathrm{P}<0.05)$. There was no significant difference $(\mathrm{P}>0.05)$ in plasma-protein and muscle protein content between the treatment groups. Nevertheless, birds fed with vegetable formulated feed exhibited higher rate of feed conversion expressed as muscle protein weight $(118.2 \pm 16.34 \mathrm{~g})$ and body weight gained $(7.1 \pm 1.74 \mathrm{~g})$ than control group muscle protein weight $(90.3 \pm 23.18 \mathrm{~g})$ and body weight gained $(4.99 \pm$ $1.66 \mathrm{~g})$. This study, therefore, indicates that low fat and high protein meat can be obtained from birds fed with the experimental vegetable formulated feeds.

Key words: Poultry, feed, broiler, lipid, protein

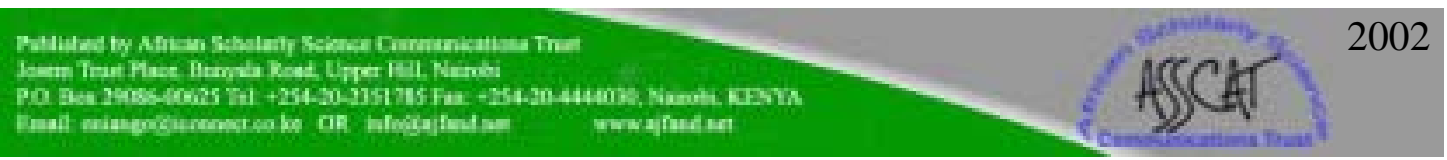




\section{INTRODUCTION}

Livestock production plays an important role in the agricultural sector of every nation particularly in the West African sub-region. The satisfactory outcomes of agricultural activities depend, to a large extent, on the use of feeds that are safe and of high quality. Livestock industries usually formulate feeds from materials that are either edible or inedible by man. These feeds, when ingested by the animals, enhance the animal productivity in terms of number and nutrient quality, to meet most of the immediate nutrient requirements of man [1].

World feed resources are on the verge of rapid decline, caused probably by increase in the number of humans and human activities. Hence, it is inevitable that conventional animal feeds should become increasingly more expensive. This has led to a search for new, often unconventional feeds, and effective methods of processing presently inedible roughages into more acceptable and nutritious feeds [1].

Agricultural practice in West Africa, and indeed most developing countries, consists of small- scale farming. The farmers in this sub-region have, in general, low level of agricultural education and at the same time are handicapped by insufficient capital. According to Payne and Wilson [1], the unavailability of capital and increasing worldwide cost of energy, purchased feeds, equipment and pharmaceuticals may in the long run delay or even halt the complete industrialization and urbanization of poultry production in tropical countries. Under such circumstances, subsistence and small-scale production methods with additional improvements may become relatively attractive to this sector of the population $[1,2]$.

Feed ration (formulation) involves combining different ingredients in proportions necessary to provide the animal with proper amounts of nutrients needed at a particular growth stage. The ration should be palatable to the animals and not cause any serious digestive disturbances. [2]. Different species of animals have different requirements for energy (carbohydrate and fat), proteins, minerals and vitamins in order to maintain functions like homeostasis, reproduction, egg production, lactation and growth [3]. Feed formulation does not merely involve mathematical calculations but factors such as cost, presence of anti-nutritional factors, texture, moisture, processing, digestibility and acceptability to the animal [2]. One of the most important roles of animal production is to provide high quality protein for human consumption; to achieve this, animals should be fed correct proportions of high quality protein [4]. Broilers are fast growing birds, which mature at 8 to 10 weeks; they are tender-meated with soft, pliable and smooth textured skin depending on feed type and management $[5,6]$. A targeted live weight of $1.8 \mathrm{~kg}$ is attained at 12 weeks. There are two types of broiler rations, namely, the broiler starter mash fed from day one to fourth or fifth week and the broiler finisher mash, fed from week 4 or 5 until slaughter.

Today, poultry industries are highly commercial and nutrition is by far the most important single factor accounting for $65-75 \%$ of the inputs in the industry. Currently,

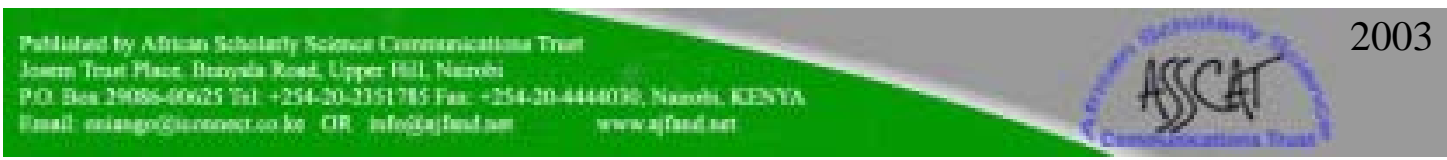


most poultry are given fat-rich meals which impact negatively on the quality of products and in turn affect humans after consumption. However, poultry farmers have been trying several alternatives of feed formulation to enhance feed quality on meat and egg production [3,7]. One of the major problems encountered in the tropics especially by small-scale farmers who wish (or are forced by lack of funds) to formulate their own rations is inadequate knowledge of poultry nutrition. When poultry diets are designed using conventional foodstuffs, they follow a fairly predictable pattern and approximate quantities of the various ingredients. Another handicap for these local small poultry farmers is the inaccessibility of the vitamin and mineral premix and lack of data on the average nutrient content of the many local foodstuffs in the ration [8]. Vegetable-based feeds are a rich source of essential plant amino acids, vitamins, minerals and antioxidants. Further to the rich contents mentioned, it has been established that green vegetable leaves are the cheapest and most abundant source of proteins because of their ability to synthesize amino acids from a wide range of available primary materials such as water, carbon dioxide and atmospheric nitrogen [9]. This study, therefore, investigated the effect of vegetable substitute for vitamin pre-mix, lysine and methionine in commercial broiler starters' mash on the fat and protein content of meat production.

\section{MATERIALS AND METHODS}

The experiment was carried out at the poultry unit of the Department of Agriculture, Babcock University, Ogun State, Nigeria. Fifty day-old chicks were purchased from Joy Veterinary Services and randomly distributed into two groups: control and experimental groups. The two groups were fed and given water ad libitum throughout the experiment. The control groups were fed commercial broiler starters' mash while the experimental groups were fed vegetable-based formulated feed. Slurry of $10 \mathrm{~kg}$ of pawpaw and $10 \mathrm{~kg}$ of banana was made by blending them into pulp of uniform mixture. The slurry was mixed with grounded maize, soya bean cake, groundnut cake, fish meal, palm kernel cake, bone meal, oyster shell and salt $(\mathrm{NaCl})$. The mixture was sun- dried for $48 \mathrm{~h}$. Ten $\mathrm{kg}$ of pumpkin leaves were also sun-dried for $48 \mathrm{~h}$ and milled together with the dried slurry mixture to form the experimental diet.

It is important to note that there are several methods of feed formulations including the square method, simultaneous equation method, two- by- two-matrix-method, trialand- error method and linear programming method. For this study, trial-and-error method of feed formulation was adopted. Birds that were cared for 6 weeks were administered glucose, vitamins and antibiotics on the first day of experiment. Gumboro vaccine was administered on the $7^{\text {th }}$ day while from the $19^{\text {th }}$ to the $20^{\text {th }}$ day of the experiment, the birds were given coccidiostat. Water was given twice daily to the birds only for the last 6 days prior to slaughtering. Six (6) birds were randomly selected from each group and slaughtered. The protein concentration was determined according to Lowry et al. [10] using bovine serum albumin (BSA) as standard, while the percentage crude protein, moisture and ash content of organs including the head, gizzard, heart, lung, small intestine, large intestine, upper limbs, lower limbs and liver

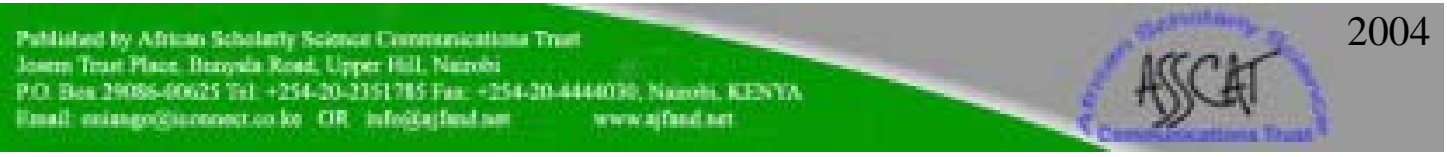


were determined according to Pearson's Chemical Analysis of Foods [11]. Live performance of broilers in terms of muscle protein weight and body weight gain was assessed according to Baker and Chung [12] and Degussa [13].

\section{STATISTICAL ANALYSIS}

All data obtained from determinations of percentage crude protein, moisture ash and fat content in vegetable and standard formulated feeds as well as plasma and muscle protein, weight of organs and fat contents of experimental and control birds were subjected to SPSS for Windows version 15.0 statistical package. Comparison of means was done using paired sample $t$ test. $P$ value less than 0.05 was considered to be significant. Data were reported as mean \pm standard deviation.

\section{RESULTS}

The results in Table 2 show that vegetable-based feed formula contained a significantly $(\mathrm{P}<0.05)$ higher crude protein $(15.75 \pm 0.14 \%)$ and moisture content $(23.3 \pm 2.36 \%)$ than those of standard commercial feed formula crude protein $(9.63 \pm$ $0.13 \%)$ and moisture content $(16.7 \pm 2.23 \%)$. The ash content $(10.0 \pm 4.08 \%)$ and fat composition $(2.5 \pm 0.78 \%)$ were the same in both feed formula (Table 2). There was no statistically significant difference $(\mathrm{P}>0.05)$ in organ weights (head, gizzard, liver, heart, lungs, small intestine, large intestine, upper limbs and lower limbs) between experimental and control groups. Fat analysis indicated a significant $(\mathrm{P}<0.05)$ decrease in the serum total cholesterol and mean fat composition in the serum, heart, gizzard and muscles of the experimental groups than the control group (Table 3). There were, also, no significant differences $(\mathrm{P}>0.05)$ in the plasma protein and muscle protein contents between experimental and control groups. However, the vegetablebased fed birds had a higher muscle protein weight and body weight gain than commercial starter fed bird (Table 3).

\section{DISCUSSION}

The present study aimed to determine the possibility of vegetable-based feed formula in enhancing the quality of poultry meat produced by broilers in terms of the proteinlipid ratio. Trial- and- error method was used in the process of compounding an experimental feed that included banana and pawpaw and vegetables such as pumpkin leaves to the well known commercial broiler starter feed formula as shown in table 1 . Previous studies [9] show that vegetable-based feeds are rich sources of essential plant amino acids, vitamins, minerals and antioxidants. In addition to the bioavailability of these essential nutrients, the green vegetables are the cheapest and most abundant source of proteins because of their ability to synthesize amino acids from a wide range of virtually available primary materials such as water, carbon dioxide, and atmospheric nitrogen [9]. The proximate analysis of both experimental and standard feed formula revealed a higher crude protein and moisture content in experimental feed than commercial feed, while their ash contents were estimated to be

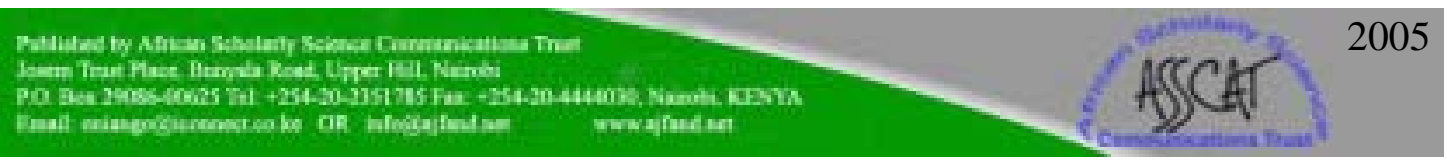


the similar. These could be deduced from the presence of the leafy vegetables in the experimental formulated diet. There was no significant difference in the average weight of both the experimental and control groups head, gizzard, liver, heart, small and large intestines. However, the weight of the experimental birds' lungs and limbs were lower compared to those of the control group. These might have resulted from high fat deposit in the body of control birds [14]. Fat content analysis indicated a significant decrease in the serum total cholesterol and mean fat composition in heart, gizzard and muscles of the experimental group compared to the control group. This is in agreement with previous reports that vegetables and fruits decrease fat deposit in the body $[14,15]$. Furthermore, no significant differences were found between the plasma-protein and muscle- protein contents of the experimental and control groups. Nevertheless, the vegetable-fed birds had higher muscle- protein weight and body weight gain compared to commercial starter mash fed birds. This indicates a better live performance and feed muscle conversion rate $[13,14]$. Feed quality is a major player in the production performance of the animal. It is also the beginning of the animal protein production chain, hence, the need to address consumption concerns over food safety. Thus, the present study tends to support the view that vegetablebased broiler feed formulation will enhance the quality of poultry produce in terms of meat production.

\section{CONCLUSION}

The study indicated that low fat and high protein meat can be obtained from birds fed with experimental vegetable feed than those fed with commercial broiler's starter mash. Therefore, the vegetable-based products serve as a source of the essential ingredients required by poultry farmers during the formulation of broilers' feed. The vegetable feed formula may enhance the poultry meat products in terms of nutritive value that would in the long run be beneficial to the health of meat consumer's and possibly serve as a source of economic value to the poultry farmers.

It is recommended that the addition of vegetable-based products in poultry feed formula would serve as a cheap source of amino acids, antioxidants, vitamins and bioactive metabolites, that are necessary for the growth and development of broiler birds. The production of such birds could in turn improve the health status of meateaters by boosting their immunity. This would contribute greatly towards the prevention and reduction of neurodegenerative diseases associated with lipid-rich diet. Hence, the adoption of green vegetables and vegetable pulp substitutes for pre-mixed vitamins during feed formulation in West Africa and other developing nations, would serve as a cheap and natural source of ingredient in poultry feed formulation for small scale farmers.

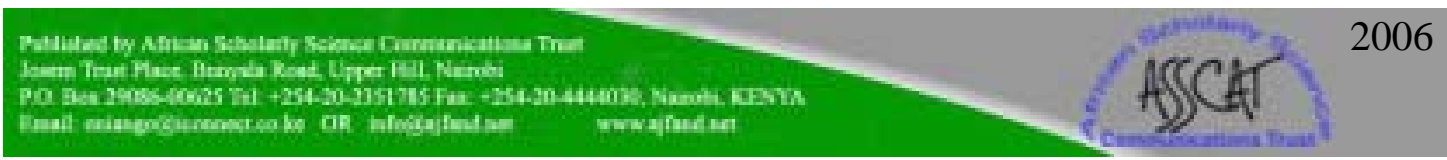




\section{ACKNOWLEDGEMENTS}

We thank Mr. Gibson O. Chioma, the Head of Poultry Unit, Department of Agriculture and Industrial Technology, Babcock University for his invaluable assistance and provision of working facilities. Our gratitude goes to Asaolu O. Ikeoluwapo for her active participation during the course of the research. 


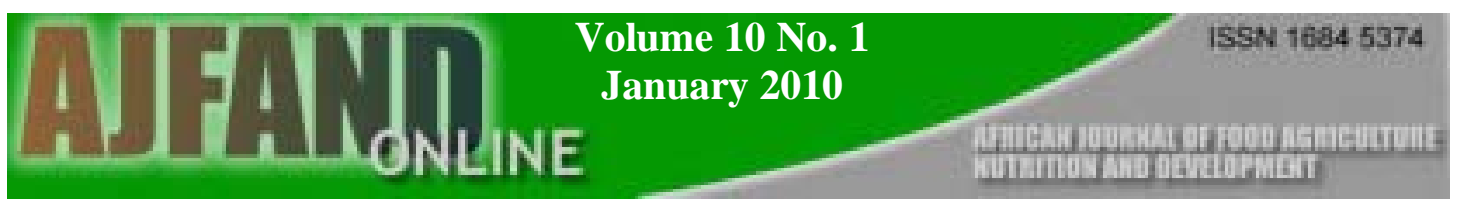

Table 1: Feed formulation for control and experimental diet

\begin{tabular}{|c|c|c|c|c|}
\hline Ingredient & Control (kg) & $\begin{array}{c}\text { Percentage } \\
\text { composition }\end{array}$ & $\begin{array}{c}\text { Experimental diet } \\
\text { (Kg) }\end{array}$ & $\begin{array}{c}\text { Percentage } \\
\text { composition }\end{array}$ \\
\hline Maize & & & & \\
Soya bean cake & 15 & 30.7 & 15 & 18.8 \\
Groundnut cake & 6.25 & 12.5 & 6.25 & 7.83 \\
Fish meal & 6.25 & 12.5 & 6.25 & 7.83 \\
Wheat offal & 2.25 & 4.5 & 2.25 & 2.82 \\
Palm kernel cake & 12.9 & 25.8 & 12.9 & 16.16 \\
Bone meal & 4.8 & 9.6 & 4.8 & 6.02 \\
Oyster shell & 1.25 & 2.5 & 1.25 & 1.57 \\
Vitamin pre-mix & 1.0 & 2.0 & 1.0 & -11 \\
Lysine & 0.1 & 0.2 & - & - \\
Methionine & 0.024 & 0.048 & - & - \\
Salt & 0.048 & 0.096 & - & 0.16 \\
Pumpkin leaves & 0.125 & 0.25 & 0.125 & 12.53 \\
Banana & - & - & 10 & 12.53 \\
Pawpaw & - & - & 10 & 12.53 \\
\hline
\end{tabular}

Table 2: Percentage crude protein, moisture, ash and fat content feeds

\begin{tabular}{ccccc}
\hline \multirow{2}{*}{ Feed } & \multicolumn{4}{c}{ Percentage } \\
\cline { 2 - 5 } & $\begin{array}{c}\text { Crude } \\
\text { protein }\end{array}$ & Moisture & Ash & Fat \\
\hline $\begin{array}{c}\text { Standard } \\
\text { Formula }\end{array}$ & $9.63 \pm 0.13^{*}$ & $16.7 \pm 2.23$ & $10.0 \pm 4.08$ & $2.5 \pm 0.78$ \\
$\begin{array}{c}\text { Vegetable } \\
\text { formula }\end{array}$ & $15.75 \pm 0.14^{\ddagger}$ & $23.3 \pm 2.36^{\ddagger}$ & $10.0 \pm 4.08$ & $2.5 \pm 0.78$ \\
\hline$*$ indicates mean \pm standard deviation & ${ }^{\ddagger}$ significant at $\mathrm{P}<0.05$ &
\end{tabular}


Table 3: Weight and fat contents from vegetable fed and starter fed (control) Birds

\begin{tabular}{|c|c|c|}
\hline Organs weight (g) & Experimental birds & Control birds \\
\cline { 1 - 2 } Head & $41.2 \pm 9.49^{*}$ & $54.5 \pm 9.16$ \\
Gizzard & $33.8 \pm 4.88$ & $37.2 \pm 6.09$ \\
Liver & $15.5 \pm 2.58$ & $16.7 \pm 4.25$ \\
Heart & $3.1 \pm 0.39$ & $3.2 \pm 0.88$ \\
Lungs & $3.5 \pm 0.56$ & $5.4 \pm 0.87$ \\
Small Intestine & $18.2 \pm 2.29$ & $18.1 \pm 4.11$ \\
Large Intestine & $28.9 \pm 7.13$ & $30.9 \pm 1.33$ \\
Upper Limbs & $37.2 \pm 15.2$ & $52.2 \pm 8.79$ \\
Lower limbs & $83.3 \pm 11.49$ & $145.0 \pm 27.23$ \\
\cline { 1 - 1 } Fat content (mg/dl) & $0.6 \pm 0.17$ & $1.2 \pm 0.30$ \\
\cline { 1 - 1 } Heart & $1.6 \pm 0.30$ & $2.6 \pm 0.30$ \\
Gizzard & $38.7 \pm 8.10^{\ddagger}$ & $78.3 \pm 10.76$ \\
Muscle & $42.3 \pm 30.02^{\ddagger}$ & $237.4 \pm 173.5$ \\
Total Serum Cholesterol & & \\
\cline { 1 - 1 } Tissue protein (mg/ml) & & $0.5 \pm 0.14$ \\
\cline { 1 - 1 } Plasma protein & $0.5 \pm 0.12$ & $10.6 \pm 2.95$ \\
Muscle protein & $12.0 \pm 3.00$ & \\
\cline { 1 - 1 } Live performance (g) & & \\
\cline { 1 - 1 } Muscle protein weight & $118.2 \pm 16.34^{\ddagger}$ & $90.3 \pm 23.18$ \\
Body weight gained & $7.1 \pm 1.74^{\ddagger}$ & $4.99 \pm 1.66$ \\
\hline$y$
\end{tabular}

$*$ indicates mean \pm standard deviation ${ }^{*}$ significant at $\mathrm{P}<0.05$ 


\section{REFERENCES}

1. Payne WJA and RT Wilson An Introduction to Animal Husbandry in the Tropic. Blackwell Science Limited, London. 1999: 59- 616.

2. Leeson S Animal and Poultry Science. Balliere Tindal, London. 2000: 154-161.

3. Ensminger ME Animal Science Digest. Cloris, California. 1991: 457-458.

4. Araújo LF, Junqueira OM, Araújo CS, Faria DE and MO Andreotti Different Criteria of Feed Formulation for Broilers Aged 43 to 49 Days. Rev. Bras. Cienc. Avic. 2004; 6(1): 61-64.

5. Kekeochs CC Poultry Production in the Tropics. Sibon Books Limited, Ibadan. 1998:52-54.

6. Oluyemi JA and FA Roberts Poultry Production in Warm Wet Climates. Spectrum Books Limited, Ibadan. 2000:153-156.

7. Vieira SL and IL Lima Live Performance, Water Intake and Excreta Characteristics of Broilers Fed All Vegetable Diets Based on Corn and Soybean Meal. Int. J. Poultr. Sci. 2005; 6:365-368.

8. Anthony JS Tropical Agriculturist. Macmillan Education Limited, London. 2001: 82-91.

9. Fasuyi AO Nutritional potentials of some tropical vegetable leaf meals: chemical characterization and functional properties. Afri. J. Biotec. 2006; 5(1): 49-53.

10. Lowry OH, Rosebrough NJ, Farr AL and RJ Randal Protein Measurement with Folin Phenol Reagent. J. Biol. Chem. 1951; 193: 265-275.

11. Egan H, Kirk RS and R Sawyer Flesh Foods. Pearson's Chemical Analysis of Foods. Churchill Livingstone, London. 1985: 383-431.

12. Baker DH and TK Chung Ideal Protein for Swine and Poultry. Biokyowa Publishing Co., St. Louis. 199: 1-17.

13. Degussa AG Amino Acid Recommendation for Poultry. Feed Formulation Guide. Hanau. 1997.

14. Nelson $\mathbf{D}$ and $M$ Cox Lipids Biosynthesis. Lehninger Principles of Biochemistry. W.H. Freeman and Company, New York. 2005: 787-828. 
15. Zanini SF, Colnago GL, Pessotti BMS, Bastos MR, Casagrande FP and VR Lima Body Fat of Broiler Chickens Fed Diets with Two Fat Sources and Conjugated Linoleic Acid. Int. J. Poult. Sci. 2006; 5(3):241-246. 